\title{
ПОРЯДОК ПРИЗНАЧЕННЯ НА ПОСАДИ ЧЛЕНІВ ВИЩОї КВАЛІФІКАЦІЙНОї КОМІСІї СУДДІВ УКРАÏHИ
}

\author{
СІТНІКОВ Віталій Вадимович - аспірант кафедри адміністративного та \\ митного права Університету митної справи та фінансів \\ УДК $351.74: 342.922$ \\ https://orcid.org/0000-0002-4389-2710 \\ DOI 10.32782/NP.2021.2.11
}

\begin{abstract}
Целью научной статьи является раскрытте порядка назначения на должности членов Ввгсшей квалибикационной комиссии судей Украинъл. Методъ статьи составила совокупность современных методов и приемов познания объективной действительности, объединяюший как общенаучнъие, так и специальнъе методъ познания. Основой исследования является диалектический метод познания, согласно которому проблемъ, рассматриваемье в диссертации, представлень в виде единства их сочиального содержания и юридической бормъл.

ВРП должен создать конкурсную комиссию, в состав которой будут входить: три лииа, избраннье Советом судей Украиньл среди ее иленов; три человека из числа «международных экспертов, предложеннъхх международнъими организациями, с которьми Украина сотрудничает в сфере предотвращения и противодействия коррупиии в соответствии с международнъими договорами Украинъ, в состав Общественного совета международнъхх экспертов, созданной в соответствии с законом «О Выссшем антикоррупиионном суде». При этом следует обратить внимание, что в соответствии с и. $3 \mathrm{~cm} .95-1$ Закона Украинь «О судоустройстве и статусе судей» в редакиии Закона решение конкурсной комиссии будет считаться принятьлм, если за него проголосовало большинство от присутствующих членов конкурсной комиссии, если только три человека из иисла проголосовавших за это решение являются международнъими экспертами. То есть, если за решение проголосовало два
\end{abstract}

международнье эксперть и два человека, избраннъе Советом судей Украинъ, несмотря на принятие такого решения большинством, оно будет считаться не принятьим, поскольку условие, закрепленное в этой норме «три человека из иисла проголосовавших за это решение, является международнъими экспертами», не въпполнено. Похожую конструкиию относительно принятия решения / голосования Комиссией по вопросам добропорядочности и этики (в ее состав будут входить три члена ВРП и три международнъе экспертъг) содержит и ст. 28-1 Закона Украинъ «О Вьисшем совете правосудия» в редакиии Закона.

Ключевъе слова: Высшая квалибикационная комиссия судей, обязанности, полномочия, права, порядок, судейский орган, илен.

\section{Постановка проблеми}

У період набуття Україною ознак демократичної, соціальної, правової держави проблема кадрового забезпечення судової влади набуває особливого значення. У правовій державі суддям надається виняткова роль, на відміну від інших гілок влади судова влада надається судді особисто [1].

У будь-якій країні завжди було актуальним питання здійснення правосуддя, а отже, і питання рівня кваліфікації суддів. 3 цією метою і була створена Вища кваліфікаційна комісія суддів в Україні.

Вища кваліфікаційна комісія суддів України є державним органом суддівського врядування, який на постійній основі діє у системі правосуддя України. 
Вища кваліфікаційна комісія суддів України - чинний державний колегіальний орган у системі судоустрою України, відповідальний за формування суддівського корпусу, переведення суддів, забезпечення їх належного кваліфікаційного рівня.

\section{Огляд останніх досліджень та публікацій}

На сьогодні в науковій літературі практично відсутні дослідження, які грунтуються на оновленому законодавстві у сфері судоустрою та присвячені визначенню ролей ВККСУ в організації роботи судів.

Окремі аспекти діяльності ВККСУ досліджували такі вчені, як А. А. Борко, В. Д. Бринцев, О.В.Гончаренко, В.В.Долежан, Р. В. Ігонін, М. Г. Мельник, А. М. Москвич, І. В. Назаров, Ю. Є. Полянський, О. М. Терлецький та багато інших [2].

Метою статті $\epsilon$ розкриття порядку призначення на посади членів Вищої кваліфікаційної комісії суддів України.

\section{ВикАад основного матеріалу}

Відповідно до ст. 95 ЗУ «Про судоустрій і статус суддів» призначення на посади членів ВККСУ здійснюється ВРП за результатами конкурсу в порядку, передбаченому цим Законом [3].

Конкурс на зайняття посади члена ВККСУ проводить ВРП на основі принципів верховенства права, публічності та політичної нейтральності в порядку, визначеному цим Законом. Особа, яка відповідає вимогам, визначеним цим Законом до члена ВККСУ, та має намір бути призначеною членом ВККСУ, звертається до секретаріату ВРП із заявою. Форма заяви затверджується ВРП [3].

Разом із заявою про намір бути призначеною членом ВККСУ відповідна особа подає:1) автобіографію; 2) мотиваційний лист, в якому викладаються мотиви для призначення членом ВККСУ; 3) копію документа, що посвідчує особу та підтверджує громадянство України; 4) копію трудової книжки (за наявності); 5) декларацію особи, уповноваженої на виконання функцій держави або місцевого самоврядування; 6) копії документів про освіту, вчені звання та наукові ступені; 7) довідку ме- дичної установи про стан здоров'я кандидата із висновком щодо його придатності до роботи на посаді, пов'язаній із виконанням функцій держави; 8) копію військового квитка (для військовослужбовців або військовозобов'язаних); 9) письмову згоду на обробку персональних даних та оприлюднення копій документів, визначених цією статтею, крім копій документів, визначених пунктами $3,7,8$ цієї частини; 10) письмову заяву про відсутність обмежень щодо членства у ВККСУ, а також про відповідність вимогам щодо несумісності або зобов'язання виконувати вимоги щодо несумісності у разі обрання членом Комісії; 11) заяву про проведення перевірки, визначеної ЗУ «Про очищення влади»; 12) згоду на проведення спеціальної перевірки відповідно до закону [4].

Секретаріат ВРП приймає документи у хронологічному порядку надходження заяв та не пізніше наступного робочого дня оприлюднює отриману інформацію разом із копіями поданих документів, крім документів, які визначені пунктами $3,7,8$ частини четвертої цієї статті, на своєму веб-сайті [3].

Прийом документів завершується о 24 годині останнього дня строку, визначеного Вищою радою правосуддя для подання документів. Секретаріат ВРП не має права відмовити в прийнятті документів з інших підстав, ніж закінчення зазначеного строку [3].

$\mathrm{He}$ пізніше наступного дня після завершення прийому документів секретаріат ВРП формує перелік кандидатів, який невідкладно оприлюднюється на офіційному веб-сайті ВРП.

Повідомлення про час і місце проведення конкурсу публікується у газеті «Голос України» та оприлюднюється на веб-сайті ВРП не пізніше ніж за 10 днів до початку конкурсу. Секретаріат ВРП забезпечує проведення спеціальної перевірки стосовно кандидатів, щодо яких конкурсною комісією прийнято таке рішення.

Відповідно до ст. 95-1 3У «Про судоустрій та статус суддів» [3] ВРП для проведення конкурсу на зайняття посади члена ВККСУ утворюється конкурсна комісія та затверджується iї персональний склад.

До складу конкурсної комісії входять:

1) три особи, обрані Радою суддів України 3 числа їі членів; 


\section{Адміністративне право}

2) три особи з числа міжнародних експертів, запропонованих міжнародними та іноземними організаціями, з якими Україна співпрацює у сфері запобігання та протидії корупції відповідно до міжнародних договорів України, до складу Громадської ради міжнародних експертів, утвореної відповідно до ЗУ «Про вищий антикорупційний суд» [5].

Порядок отримання ВРП пропозицій від міжнародних та іноземних організацій щодо осіб із числа міжнародних експертів визначається положенням про конкурс. Положення про конкурс затверджує ВРП. Регламент роботи конкурсної комісії ухвалюється членами комісії на її першому засіданні. Рішення комісії вважається прийнятим, якщо за нього проголосувала більшість від присутніх членів конкурсної комісії за умови, що три особи з числа тих, які проголосували за це рішення, є міжнародними експертами [6].

Член конкурсної комісії має право брати участь у засіданнях і прийнятті рішень Комісії у віддаленому режимі з використанням електронних засобів зв' язку.

Конкурсна комісія має право: 1) збирати, перевіряти та аналізувати інформацію щодо кандидатів на посаду члена ВККСУ; 2) надавати ВРП і запитувати у неї інформацію щодо кандидатів на посаду члена Вищої кваліфікаційної комісії суддів України; 3) вживати заходи щодо захисту персональних даних, інформації з обмеженим доступом, які стали відомі членам конкурсної комісії у зв'язку зы здійсненням ними своїх повноважень [6].

Член конкурсної комісії зобов’язаний: особисто брати участь у іï роботі, без права делегування своїх повноважень іншим особам; не використовувати інакше, ніж для виконання своїх обов'язків, персональні дані та іншу інформацію, що стала відома у зв'язку з участю в роботі конкурсної комісії; відмовитися від участі у зборі інформації про кандидата, розгляді питання про відповідність кандидата на посаду, якщо член конкурсної комісії перебуває чи перебував в особистих чи ділових стосунках із кандидатом та/або у разі наявності іншого конфлікту інтересів або обставин, що можуть вплинути на об'єктивність чи неупередженість під час прийняття членом комісії рішення щодо зайняття кандидатом посади члена ВККСУ [6].
Організаційно-технічне забезпечення діяльності конкурсної комісії здійснює Вища рада правосуддя. Фінансування діяльності конкурсної комісії може здійснюватись із залученням міжнародної технічної допомоги. Члени конкурсної комісії, які постійно не проживають на території України, мають право на компенсацію витрат на проживання в Україні та переїзд [6].

Конкурсна комісія розглядає документи, подані кандидатами на посаду члена ВККСУ; відбирає із загальної кількості кандидатів тих, які згідно з обгрунтованим рішенням конкурсної комісії мають найкращі професійний досвід, знання і якості для виконання обов'язків члена ВККСУ та відповідають вимогам закону; оприлюднює на офіційному веб-сайті ВРП інформацію про кандидатів, відібраних для проходження співбесіди з конкурсною комісією; проводить на своєму засіданні співбесіду 3 відібраними кандидатами, відбирає шляхом відкритого голосування 3 числа кандидатів, які пройшли співбесіду, на кожну вакантну посаду одного кандидата, який відповідає вимогам до члена ВККСУ та згідно з обгрунтованим рішенням конкурсної комісії має найкращі професійний досвід, знання і якості для виконання обов'язків члена ВККСУ [6].

Члени ВККСУ призначаються шляхом прийняття рішення ВРП на їі засіданні на підставі протоколу конкурсної комісії, підписаного усіма іï членами, які були присутні на відповідному засіданні конкурсної комісії під час складання такого протоколу. У разі дострокового припинення повноважень члена ВККСУ Вища рада правосуддя упродовж десяти днів розміщує оголошення про умови та строки проведення конкурсу на офіційному веб-сайті ВРП [6].

Відповідно до ст. 96 ЗУ «Про судоустрій і статус суддів» [3] підставами для звільнення члена ВККСУ 3 посади є: 1) подання заяви про звільнення з посади члена Комісії за власним бажанням; 2) неспроможність виконувати свої повноваження за станом здоров'я ( за наявності медичного висновку); 3) виявлення обставин щодо його невідповідності вимогам, установлених цим Законом; 4) порушення вимог, установлених законодавством у сфері запобігання корупції; 5) неучасть у роботі Комісії протягом одного календарного місяця 
поспіль без поважних причин або неодноразова відмова без поважних причин від голосування з питань, що розглядаються; 6) грубе чи систематичне нехтування обов'язками, що є несумісними із статусом члена ВККСУ або виявило його невідповідність займаній посаді, допущення іншої поведінки, що підриває авторитет та суспільну довіру до правосуддя і судової влади, у тому числі недотримання етичних стандартів судді як складової професійної етики члена ВККСУ [3].

Рішення про звільнення члена ВККСУ ухвалює ВРП на своєму засіданні більшістю голосів від ії складу, визначеного Законом України «Про Вищу раду правосуддя» [7]. Рішення про звільнення члена ВККСУ з посади з підстав, визначених пунктами 1 і 2 частини першої цієї статті, ухвалює ВРП на найближчому засіданні після отримання заяви. Рішення про звільнення члена ВККСУ з підстав, визначених пунктами 3-6 частини першої статті 96 3У «Про судоустрій та статус суддів» [3], ухвалюється ВРП на підставі подання Комісії 3 питань доброчесності та етики, утвореної відповідно до ЗУ «Про Вищу раду правосуддя» [7]. 3 дня внесення зазначеного подання такий член Комісії відсторонюеться від посади. У разі встановлення підстав для звільнення члена ВККСУ з посади, визначених пунктами 3-6 частини першої цієї статті, ВККСУ може своїм рішенням внести до ВРП подання про звільнення 3 посади відповідного члена комісії. 3 дня ухвалення рішення Комісії про внесення зазначеного подання такий член Комісії відсторонюється від посади, а його повноваження зупиняються до прийняття рішення ВРП. Процедура розгляду та ухвалення рішення про звільнення члена ВККСУ здійснюється відповідно до вимог Регламенту ВРП.

Повноваження члена ВККСУ припиняються у разі: 1) закінчення строку, на який його обрано (призначено); 2) набрання законної сили обвинувальним щодо нього вироком суду; 3) припинення громадянства України або набуття громадянства іншої держави;4) визнання його безвісно відсутнім або оголошення померлим, недієздатним або обмежено дієздатним; 5) смерті члена Комісії; 7) набрання законної сили рішення суду про визнання його активів або активів, набутих за його дорученням іншими особами або в інших перед- бачених ст. 290 Цивільного процесуального кодексу України випадках, необгрунтованими та їх стягнення в дохід держави [8].

ВККСУ пленарним складом обирає таємним голосуванням більшістю голосів від загального складу Голову ВККСУ і заступника Голови, які є головами палат, та секретарів палат ВККСУ. Головує на цьому засіданні член ВККСУ, який має найбільший стаж професійної діяльності у сфері права [3].

Голова ВККСУ організовує роботу Комісії, визначає обов'язки заступника Голови, веде засідання Комісії, здійснює підготовку засідань ВККСУ та організовує діловодство [3].

Обов'язки Голови ВККСУ в разі його відсутності виконує заступник Голови Комісії, а за відсутності заступника Голови - член Комісії, обраний за квотою з'їзду суддів України, який має більший стаж роботи на посаді судді. Голова ВККСУ видає накази, розпорядження та доручення, які є обов'язковими до виконання членами ВККСУ та працівниками секретаріату [2].

Секретарі палат ВККСУ здійснюють підготовку засідань палат та несуть відповідальність за організацію діловодства у цих палатах.

Організаційне забезпечення діяльності ВККСУ здійснює секретаріат. Секретаріат очолює його керівник, який призначається на посаду за результатами конкурсу з урахуванням положень цього Закону та Закону «Про державну службу» [9].

Для здійснення розподілу справ у ВККСУ діє автоматизована система визначення члена ВККСУ, який проводить підготовку до розгляду і доповідає справу. Голови палат ВККСУ організовують роботу палат та ведуть засідання палат. Обов'язки голів палат у разі їх відсутності виконують члени палат, призначені за квотою з'їзду суддів України, які мають більший стаж роботи на посаді судді [2].

ВККСУ затверджує Регламент, у якому регулюються відповідно до цього Закону процедурні питання іï діяльності [3].

Засідання ВККСУ, іiї палат та колегій проводяться відкрито, крім випадків, установлених законом. Засідання Комісії, її палат є повноважним, якщо в ньому бере участь більшість від складу Комісії або палати відповідно [6].

Голова ВККСУ визначає дату, час і місце проведення засідання Комісії, перелік питань, 


\section{Адміністративне право}

що виносяться на засідання, і не пізніше як за десять днів до засідання повідомляє про це особу, щодо якої має розглядатися питання, та оприлюднює цю інформацію на офіційному веб-сайті ВККСУ (крім засідань з організаційних питань) [6].

Голови палат Комісії визначають дату, час i місце проведення засідань відповідних палат, перелік питань, що виносяться для розгляду на засіданні, і не пізніше як за десять днів до засідання повідомляють про це осіб, щодо яких має розглядатися питання, та оприлюднюють цю інформацію на офіційному веб-сайті ВККСУ [3].

У Ст. 99 ЗУ «Про судоустрій і статус суддів» [3] визначає права члена ВККСУ. Зокрема, член ВККСУ має право: 1) знайомитися 3 матеріалами, поданими на розгляд Комісії, відповідної палати, членом якої він є, колегії, брати участь у їх дослідженні та перевірці;2) наводити свої мотиви та міркування, а також подавати додаткові документи 3 питань, що розглядаються; 3) вносити пропозиції щодо проєкту рішення ВККСУ з будь-яких питань та голосувати «за» або «проти» того чи іншого рішення; 4) висловлювати письмово окрему думку щодо рішення ВККСУ; 5) здійснювати інші повноваження, встановлені законом [3].

Член ВККСУ не має права брати участь у розгляді питання та ухваленні рішення і підлягає відводу (самовідводу), якщо наявні дані про конфлікт інтересів або обставини, що викликають сумнів у його безсторонності. За наявності таких обставин член ВККСУ повинен заявити самовідвід. Із тих самих підстав відвід члену комісії можуть заявити особи, щодо яких або за поданням яких розглядається питання. Відвід має бути вмотивованим і поданим до початку розгляду питання у формі письмової заяви. Головуючий на засіданні зобов'язаний ознайомити із заявою про відвід члена Комісії, якому заявлено відвід. Рішення про відвід(самовідвід) ухвалюється більшістю голосів членів ВККСУ, які беруть участь у засіданні. Голосування проводиться за відсутності члена комісії, щодо якого вирішується питання про відвід (самовідвід) [10].

Рішення ВККСУ у пленарному засіданні ухвалюється більшістю від установленого цим Законом складу Комісії. Голосування проводиться за відсутності особи, щодо якої вирішу- ється питання, та інших осіб, які не є членами Комісії. Рішення Палати ВККСУ ухвалюється більшістю від складу палати 3 урахуванням членів іншої палати в разі їх залучення до участі в розгляді відповідного питання. Рішення колегії ВККСУ ухвалюється більшістю голосів. Палати та колегії ВККСУ ухвалюють свої рішення від імені ВККСУ, зазнаючи склад палати чи колегії, який розглядав конкретну справу. ВККСУ може переглядати рішення, прийняті палатою чи колегією, щодо допуску до конкурсу або добору. Рішення ВККСУ, палат та колегій Комісії викладаються у письмовій формі. У рішенні зазначаються дата і місце ухвалення рішення, склад Комісії (палати, колегіï), питання, що розглядалося, мотиви ухваленого рішення. Рішення підписується голова і членами Комісії (палати, колегії), які брали участь у його ухваленні. За наявності окремої думки члена ВККСУ вона викладається у письмовій формі і додається до справи, про що голова повідомляє на засіданні. Рішення Вищої кваліфікаційної комісії суддів можуть бути оскаржені до суду з підстав, установлених Законом. Рішення ВККСУ щодо надання рекомендацій можуть бути оскаржені тільки разом $з$ рішенням, ухваленим за відповідною рекомендацією [10].

У разі наявності окремої думки двох або більше членів палати Вищої кваліфікаційної комісії суддів, які брали участь у розгляді питання та ухвалення рішення відповідною палатою, Голова ВККСУ має право винести таке питання на розгляд ВККСУ, на якому у порядку, встановленому регламентом, ухвалюється остаточне рішення по суті питання [3].

Організаційне забезпечення діяльності ВККСУ здійснює секретаріат. Секретаріат очолює його керівник, який призначається на посаду за результатами конкурсу з урахуванням положень цього Закону та ЗУ «Про державну службу» [13]. Положення про секретаріат ВККСУ затверджується ВККСУ. Для здійснення членами ВККСУ своїх повноважень у складі секретаріату ВККСУ діє служба інспекторів у кількості, визначеній ВРП. Гранична чисельність працівників ВККСУ 3 урахуванням визначеної кількості членів Комісії та інспекторів затверджується ВРП за поданням ВККСУ. Працівники секретаріату ВККСУ призначаються на посади та звільня- 
ються з посад у порядку, встановленому законодавством про державну службу. Інспектори ВККСУ призначаються на посади та звільняються з посад Головою ВККСУ за пропозицією відповідного члена ВККСУ.

Розмір винагороди члена ВККСУ, який не є суддею, встановлюється у розмірі посадового окладу судді вищого спеціалізованого суду. Розмір винагороди члена ВККСУ, який є суддею, дорівнює сумі його суддівської винагороди, якщо така сума перевищує розмір посадового окладу судді Верховного Суду з коефіцієнтом 1,5. Виплата винагороди членам ВККСУ, заробітної плати працівникам секретаріату та інспекторам Комісії провадиться за рахунок коштів Державного бюджету України [10].

Порівняльний аналіз ст. 95-98, 102 ЗУ «Про судоустрій і статус суддів» редакція чинна до 06.11.2019 р. та ст. 92-98, 102 оновленого Закону (чинна редакція з 07.11.2019 р. [10].

Служба інспекторів ВККСУ формується 3 числа осіб, які мають повну вищу юридичну освіту і стаж професійної діяльності у сфері права понад п’ять років. У разі призначення судді у відставці інспектором Комісії за ним зберігається пенсія або довічне грошове утримання, а також інші гарантії, визначені цим Законом. Інспектори ВККСУ діють винятково за дорученням члена ВККСУ відповідно до актів, що регулюють діяльність Комісії [2].

За дорученням члена Комісії інспектори: 1) попередньо аналізують матеріали справ щодо кваліфікаційного оцінювання; 2) виконують інші завдання в межах повноважень члена Комісії, визначених цим Законом.

Службу інспекторів ВККСУ очолює керівник служби інспекторів Комісії, який підпорядковується безпосередньо Голові ВККСУ.

Інспектори ВККСУ не $\epsilon$ державними службовцями, їх статус визначається цим Законом [3]. Особливості діяльності визначаються Положенням про інспектора ВККСУ, яке затверджується ВККСУ.

\section{Висновки}

Отже, 3 дня набрання чинності Закону України «Про судоустрій і статус суддів», тобто 37 листопада 2019 року повноваження членів ВККСУ припиняються та запроваджується новий порядок формування іiї нового складу, за яким призначення на посади 12 членів ВККС (кількість зменшено з 16 членів) здійснюватиме ВРП за результатами конкурсу. Протягом дев'яноста днів 3 дня набрання чинності Закону, ВРП формує новий склад ВККСУ на підставі відкритого конкурсу. Члени ВККСУ призначаються та звільняються 3 посад за рішенням ВРП.

Серед іншого, вносяться суттєві зміни до законів «Про судоустрій і статус суддів» та «Про Вищу раду правосуддя» щодо суддівської винагороди. Документом визначається, що суддівська винагорода встановлюється за єдиними правилами для всіх суддів незалежно від умов проходження ними кваліфікаційного оцінювання, оскільки всі судді судової системи мають єдиний правовий статус і $є$ рівними перед законом.

Окрім того, закон розширює категорії посад, щодо яких здійснюються заходи 3 очищення влади (люстрації). Так, вона поширюватиметься на керівників ВККС і Державної судової адміністрації, які обіймали свої посади не менше ніж рік у період від 21 листопада 2013 року до 19 травня 2019 року.

\section{Мітература}

1. Пивовар I. В. Статус кандидата на посаду судді України. Науковий вісник Міжнародного гуманітарного університету. Серія : Юриспруденція. 2014. Вип. 8. С. 51-54

2. Терлецький О. М. Вища кваліфікаційна комісія суддів та ії роль в системі судоустрою // Матеріали III Міжнародної наукової Інтернет-конференції «Інновації та традиції в сучасній науковій думці». 2012.

3. Про судоустрій і статус суддів: Закон України від 02.06.2016 № 1402-VIII.Відомості Верховної Ради України. 2016. № 31. Ст. 545.

4. Про очищення влади: Закон України від 16.09.2014 № 1682-VII. Відомості Верховної Ради України. 2014, № 44, ст.2041.

5. Про Вищий антикорупційний суд»: Закон України від 07.06.2018 р. № 2447-VIII. Відомості Верховної Ради (ВВР). 2018. № 24. ст.212

6. Про затвердження Регламенту Вищої кваліфікаційної комісії суддів України»: Регламент Вищої кваліфікаційної комісії суддів від 13.10. 2016 року $\mathrm{N} 81 / 3 п-16$

7. Про Вищу раду правосуддя: Закон України від 21.12.2016. Відомості Верховної Ради (ВВР). 2017. № 7-8, ст.50 


\section{Адміністративне право}

\section{АНОТАЦІЯ}

Метою наукової статті є розкриття порядку призначення на посади членів Вищої квалібікаиійної комісій суддів Украӥни. Методами статті склала сукупність сучасних методів і прийомів пізнання об’єктивної дійсності, що поєднує як загальнонаукові, так $i$ спеціальні методи пізнання. Підгрунтям дослідження $є$ діалектичний метод пізнання, відповідно до якого проблеми, що розглядаються у дисертащї, представлені у вигляді єдності їх соиіального змісту та юридичної борми.

ВРП має утворити конкурсну комісію, до складу якої входитимуть: три особи, обрані Радою суддів Украйни з-поміж ї̈ иленів; три особи з иисла «міжнародних експертів, запропонованих міжнародними організачіями, 3 якими Україна співпрацюе у сбері запобігання та протидї корупціӥ відповідно до міжнародних договорів України, до складу Громадсъкоі ради міжнародних експертів, утвореної згідно із законом "Про Вищий антикорупційний суд». При иъому слід звернути увагу, що відповідно до и. $3 \mathrm{~cm}$. 95-1 ЗУ «Про судоустрій $i$ статус суддів» у редакцій Закону рішення конкурсної комісї вважатиметься прийнятим, якщо за нього проголосувала більшість від присутніх иленів конкурсної комісї, за умови що три особи з числа тих, які проголосували за ие рішення, є міжнародними експертами. Тобто, якщо за рішення проголосувало два міжнародні експерти та дві особи, обрані Радою суддів Украӥни, попри прийняття такого рішення більшістю, воно вважатиметься не прийнятим, оскільки умову, закріплену в изй нормі «три особи з числа тих, які проголосували за це рішення, є міжнародними експертами», не виконано. Схожу конструкиію стосовно прийняття рішення/голосування Комісією з питань доброчесності та етики (до ї̈ складу входитимуть три члени ВРП та три міжнародні експерти) містить $і$ ст. 28-1 3У «Про Вишу раду правосуддя» в редакиіи Закону.

Ключові слова: Вища квалібікаційна комісія суддів, обов'язки, повноваження, права, порядок, суддівсъкий орган, илен.

8. Цивільно-процесуальний кодекс України»: Закон України від 18.03.2004 р. № 1618-IV. Відомості Верховної Ради України. 2004. № 40-41, 42, ст. 492.

\section{SUMMARY}

The purpose of the scientific article is to reveal the procedure for appointment to the positions of members of the High Qualification Commission of Judges of Ukraine. The methods of the article are a set of modern methods and techniques of cognition of objective reality, which combines both general and special methods of cognition. The basis of the study is a dialectical method of cognition, according to which the problems considered in the dissertation are presented in the form of unity of their social content and legal form.

The GRP should form a competition commission, which will include: three persons elected by the Council of Judges of Ukraine from among its members; three international experts nominated by international organizations with which Ukraine cooperates in the field of preventing and combating corruption in accordance with international treaties of Ukraine, to the Public Council of International Experts established under the Law on the Supreme Anti-Corruption Court. It should be noted that in accordance with Part 3 of Art. 95-1 of the Law «On the Judiciary and the Status of Judges» as amended, the decision of the tender commission will be considered adopted if the majority of the present members of the tender commission voted for it, provided that three persons who voted for this decision are international experts. That is, if two international experts and two persons elected by the Council of Judges of Ukraine voted for the decision, despite the adoption of such a decision by a majority, it will be considered not adopted, because the condition set out in this rule "three persons who voted for this decision are international experts ", not implemented. A similar structure regarding the decision-making / voting by the Integrity and Ethics Commission (which will include three GRP members and three international experts) is contained in Art. 28-1 of the Law «On the High Council of Justice» as amended by the Law.

Keywords: High Qualification Commission of Judges, duties, powers, rights, procedure, judicial body, member.

9. Про державну службу»: Закон України від 10.12.2015 р. № 889-VIII. Відомості Верховної Ради України. 2016, № 4, ст.43

10. Про внесення змін до Закону України «Про судоустрій і статус суддів»: Закон України від 31.10.2019 р. № 193-IX. URL: http:// www.golos.com.ua/article/323610 